\title{
Synthesis, structural characterization and ionic conductivity of mixed alkali titanium phosphate glasses
}

\author{
Fatima Ezzahraa Dardar ${ }^{1}$, Michael Gross ${ }^{2}$, Saida Krimi ${ }^{3}$, Michel Couzi ${ }^{4}$, Abdessadek Lachgar 5 , \\ Said Sebti ${ }^{1}$ and Abdelaziz El Jazouli ${ }^{1, *}$ \\ ${ }^{1}$ University Hassan II of Casablanca, Faculty of Sciences Ben M'Sik, Chemistry Department, LCMS/LCPCE - \\ URAC17, Avenue Driss El Harti, Casablanca, Morocco \\ ${ }^{2}$ Department of Engineering, Center for Functional Materials, Wake Forest University, Winston-Salem, North \\ Carolina, USA \\ ${ }^{3}$ University Hassan II of Casablanca, Faculty of Sciences Ain Chock, LPCMI, Casablanca, Morocco \\ ${ }^{4}$ Université de Bordeaux, CNRS, ISM UMR 5255, 351 Cours de la Libération, F-33405 Talence Cedex, France \\ ${ }^{5}$ Department of Chemistry, Wake Forest University, Winston-Salem, North Carolina, USA
}

\begin{abstract}
Glasses with formula $\mathrm{Na}_{3-\mathrm{x}} \mathrm{Li}_{\mathrm{x}} \mathrm{CaTi}\left(\mathrm{PO}_{4}\right)_{3}\left[10(3-\mathrm{x})\right.$ mol. $\% \mathrm{Na}_{2} \mathrm{O}-10 \mathrm{x}$ mol. \% $\mathrm{Li}_{2} \mathrm{O}-20 \mathrm{~mol} . \% \mathrm{CaO}-$ 20 mol. $\left.\% \mathrm{TiO}_{2}-30 \mathrm{~mol} . \% \mathrm{P}_{2} \mathrm{O}_{5}\right](0 \leq \mathrm{x} \leq 3)$ were prepared by standard melt-quenching technique, and their structural and physical properties were characterized by thermal analysis, density measurements, Raman, and impedance spectroscopy. When $\mathrm{Na}^{+}$is gradually replaced by $\mathrm{Li}^{+}$, molar volume, glass transition temperature $\left(\mathrm{T}_{\mathrm{g}}\right)$ and ionic conductivity values decrease, pass through a minimum around the composition $\mathrm{x}=1.5$, then increase, while density values increase, pass through a maximum, then decrease. The non-linear variation of these physical properties is a result of the classical mixed alkali effect. Powder X-ray diffraction shows that crystallization of the glasses leads to the formation of a Nasicon phase for the compositions $\mathrm{x}=0$ and $\mathrm{x}=0.5$, and to a mixture of phases for the other compositions. Raman spectroscopy study shows that the glass structure contains $\mathrm{P}_{2} \mathrm{O}_{7}$ and $\mathrm{PO}_{4}$ groups, and short - Ti-O-Ti-O-Ti- chains, formed by $\mathrm{TiO}_{6}$ octahedra linked to each other through corners. These chains are linked by phosphate tetrahedra to form -O-Ti-O-P-O- linkages.
\end{abstract}

Keywords: Phosphate glasses; Mixed alkali effect; DSC/DTA; Raman; Ionic conductivity.

\section{Introduction}

Metal phosphates in both crystalline and glassy forms are extensively studied for their numerous properties and applications in various fields such as energy, health, environment and catalysis ${ }^{1-4}$. Among these phosphates, those belonging to the Nasicon family (Nasicon: sodium super ionic conductors) have attracted much attention due to their diverse properties ${ }^{5-8}$. These compounds, developed first for their remarkable ionic conductivity ${ }^{9,10}$, exhibit other characteristic properties, such as for example, low thermal expansion ${ }^{11,12}$. Also, the wide variety of possible formulations allowed the development of new materials with more specific properties such as magnetism ${ }^{13}$, luminescence ${ }^{14,15}$ or energy storage ${ }^{16}$. Some compounds of the Nasicon family can also be prepared in the glassy form; they are called Nasiglasses ( $\underline{\mathrm{Na}} \underline{\underline{s}}$ uper ionic glass $)^{17-21}$. We previously reported the structural and electrical properties of $\mathrm{Na}_{3} \mathrm{CaTi}\left(\mathrm{PO}_{4}\right)_{3}$ which exists in both crystalline and glassy forms ${ }^{20,22}$. The structure of the crystalline compound, which belongs to the Nasicon family, *Corresponding author : Abdelaziz El Jazouli Email address : eljazouli_abdelaziz@yahoo.fr DOI: http://dx.doi.org/10.13171/mjc751912040810aej consists of a three-dimensional framework built of $\mathrm{PO}_{4}$ tetrahedra sharing corners with $\mathrm{AO}_{6}$ octahedra $(\mathrm{A}=\mathrm{Ca}, \mathrm{Ti}) ; \mathrm{Na}^{+}$ions occupy the interstitial sites ${ }^{22}$. The structure of the glassy form contains $\mathrm{P}_{2} \mathrm{O}_{7}^{4-}$ and $\mathrm{PO}_{4}{ }^{3-}$ groups, and short -Ti-O-Ti-O-Ti- chains, formed by $\mathrm{TiO}_{6}$ octahedra linked by corners ${ }^{20}$. Substitution of sodium for lithium in $\mathrm{Na}_{3} \mathrm{CaTi}\left(\mathrm{PO}_{4}\right)_{3}$ led us obtaining new mixed alkali glasses: $\mathrm{Na}_{3}$ ${ }_{\mathrm{x}} \mathrm{Li}_{\mathrm{x}} \mathrm{CaTi}\left(\mathrm{PO}_{4}\right)_{3}(0 \leq \mathrm{x} \leq 3){ }^{23}$. The present work reports their synthesis, structural characterization and electrical properties.

\section{Experimental}

\section{Sample preparation}

$\mathrm{Na}_{3-\mathrm{x}} \mathrm{Li}_{\mathrm{x}} \mathrm{CaTi}\left(\mathrm{PO}_{4}\right)_{3}$ [10(3-x) mol. \% $\mathrm{Na}_{2} \mathrm{O}-10 \mathrm{x}$ mol. \% $\mathrm{Li}_{2} \mathrm{O}-20$ mol. \% CaO - 20 mol. \% $\mathrm{TiO}_{2}-30$ mol. \% $\left.\mathrm{P}_{2} \mathrm{O}_{5}\right](0 \leq \mathrm{x} \leq 3)$ glasses were prepared from $\mathrm{Na}_{2} \mathrm{CO}_{3}, \mathrm{CaCO}_{3}$, and $\mathrm{Li}_{2} \mathrm{CO}_{3}$ carbonates, $\mathrm{TiO}_{2}$ oxide, and $\left(\mathrm{NH}_{4}\right) \mathrm{H}_{2} \mathrm{PO}_{4}$ ammonium dihydrogen phosphate as starting materials (with purity not less than $99.8 \%$ ), by the melt quenching method, according to the

Received October 23, 2018

Accepted November 8, 2018

Published December 4, 2018 
following reaction scheme:

(3-x) $\mathrm{Na}_{2} \mathrm{CO}_{3}+\mathrm{x} \mathrm{Li} \mathrm{CO}_{3}+2 \mathrm{CaCO}_{3}+2 \mathrm{TiO}_{2}+6\left(\mathrm{NH}_{4}\right) \mathrm{H}_{2} \mathrm{PO}_{4} \Longrightarrow 2 \mathrm{Na}_{3-\mathrm{x}} \mathrm{Li}_{\mathrm{x}} \mathrm{CaTi}\left(\mathrm{PO}_{4}\right)_{3}+6 \mathrm{NH}_{3}+5 \mathrm{CO}_{2}+9 \mathrm{H}_{2} \mathrm{O}$

The reagent amounts required to obtain $10 \mathrm{~g}$ of glass were mixed in a mortar and transferred to an alumina boat. The powder mixture was then heated, with a rate of $10{ }^{\circ} \mathrm{C} / \mathrm{min}$, respectively to $200{ }^{\circ} \mathrm{C}, 400$ ${ }^{\circ} \mathrm{C}$ and $600{ }^{\circ} \mathrm{C}$ for 6 hours at each step. After grinding, the powder was transferred to a Pt crucible and heated $\left(10{ }^{\circ} \mathrm{C} / \mathrm{min}\right)$ to $800{ }^{\circ} \mathrm{C}(2 \mathrm{~h}), 950{ }^{\circ} \mathrm{C}(2 \mathrm{~h})$ and finally to $1050{ }^{\circ} \mathrm{C}$ (20 min). The molten glass obtained was quenched in the air in a graphite mold to create bulk samples for conductivity measurements. Under these conditions, all glasses are colorless and homogeneous, without bubbles. Bulk samples were next annealed for $4 \mathrm{~h}$ at a temperature $20^{\circ} \mathrm{C}$ below the glass transition temperature $\left(\mathrm{T}_{\mathrm{g}}\right)$, followed by slow cooling (1 ${ }^{\circ} \mathrm{C} / \mathrm{min}$ ) to room temperature, in order to remove residual stress. Bulk samples were cut as round disks of $10 \mathrm{~mm}$ and $20 \mathrm{~mm}$ in diameter and $2 \mathrm{~mm}$ thick.

\section{Chemical analysis}

Lithium and sodium concentrations for the vitreous composition $\mathrm{x}=0.5$ were determined by flame atomic emission spectrometry (FAES) using a lab-built instrument. A $5.3 \mathrm{~cm}$ slot burner head, a 25 $\mathrm{mm}$ diameter, $75 \mathrm{~mm}$ focal length fused silica lens, and a handheld Ocean Optics USB 4000 spectrometer (Ocean Optics, Dunedin, FL, USA) were used in the instrumental setup. The flame composition was controlled by different regulators set at $12.5 \mathrm{~L} / \mathrm{min}$ air and $1.0 \mathrm{~L} / \mathrm{min}$ acetylene. The integration time was 50 $\mathrm{ms}$ and standard reference solutions used in this measurement were: $20 \mathrm{ppb}, 50 \mathrm{ppb}, 100 \mathrm{ppb}, 200 \mathrm{ppb}$ $\mathrm{Li}$ and $\mathrm{Na}$ standards concentrations. $100 \mathrm{mg}$ of the corresponding glass (with composition $\mathrm{x}=0.5$ ) was diluted in $10 \mathrm{ml}$ of concentrated $\mathrm{HNO}_{3}$ to make a 100 $\mathrm{ml}$ solution. The weight percentages obtained for $\mathrm{Na}$ $(12.13 \%)$ and $\mathrm{Li}(0.803 \%)$ are close to the theoretical values (Na: $13.25 \%$; Li: $0.80 \%$ ).

\section{Density measurements}

Density measurements were performed on blocks of glasses, using Archimedes' method, on an analytical balance $( \pm 0.0001 \mathrm{~g})$ with an attached density kit; diethyl phthalate was used as the immersion liquid. The density $(\rho)$ was obtained from the following equation: $\rho=\left[\mathrm{m}_{\mathrm{a}} /\left(\mathrm{m}_{\mathrm{a}}-\mathrm{m}_{\mathrm{l}}\right)\right] \rho_{\mathrm{l}}$, where $\mathrm{m}_{\mathrm{a}}$ is the mass of the sample in air, $m_{l}$ is the mass of the sample fully immersed in the liquid, and $\rho_{1}$ is the density, at room temperature, of the liquid used (diethyl phthalate). The error in the density measurements is within $\pm 0.03 \mathrm{~g} / \mathrm{cm}^{3}$. The molar volume $\left(V_{m}=M / \rho\right)$ of the glasses was calculated from the measured density $(\rho)$ and molecular weight $(\mathrm{M})$. $\mathrm{M}$ was calculated using the following formula: $\mathrm{M}=$ $0.1(3-\mathrm{x}) \mathrm{M}_{\mathrm{Na} 2 \mathrm{O}}+0.1 \times \mathrm{M}_{\mathrm{Li} 2 \mathrm{O}}+0.2 \mathrm{M}_{\mathrm{CaO}}+0.2 \mathrm{M}_{\mathrm{TiO} 2}+$ $0.3 \mathrm{M}_{\mathrm{P} 205} ;(0 \leq \mathrm{x} \leq 3)$.

\section{Powder X-ray diffraction}

Powder X-ray diffraction (PXRD) data were collected at room temperature with a Bruker D2 Phaser XRD system, with $\mathrm{CuK} \alpha$ radiation and a Lynxeye 1D Detector, in the $2 \theta$ range of $10-60^{\circ}$ at an increment of $0.01^{\circ}$.

\section{Thermal analysis}

Differential scanning calorimetry (DSC, SDT Q600) and differential thermal analysis (DTA, DTG$60 \mathrm{H})$ were used to determine the glass transition, crystallization and melting temperatures $\left(\mathrm{T}_{\mathrm{g}}, \mathrm{T}_{\mathrm{c}}, \mathrm{T}_{\mathrm{m}}\right)$ of the glasses. Glass samples ( 20 to $40 \mathrm{mg}$ ) were transferred to platinum crucibles, and the DTA curves were recorded in an air atmosphere, with a heating rate of $10{ }^{\circ} \mathrm{C} / \mathrm{min}$ and accuracy of $\pm 5{ }^{\circ} \mathrm{C}$. The DSC curves were recorded in a flow of argon with a rate of $100 \mathrm{ml} / \mathrm{min}$ and a temperature ramp of $5^{\circ} \mathrm{C} / \mathrm{min}$.

\section{Raman spectroscopy}

Raman spectra were recorded on a confocal micro-Raman Labram (Horiba/Jobin-Yvon) spectrophotometer with a backscattering mode at room temperature in the range $150-1800 \mathrm{~cm}^{-1}$. The excitation source was a $532 \mathrm{~nm}$ continuous laser. A holographic Notch filter was used to reject the Rayleigh diffusion. The backscattered light was collected through a 100x objective and selectively transmitted toward a cooled CCD detector.

\section{Ionic conductivity}

Bulk samples (20 $\mathrm{mm}$ and $10 \mathrm{~mm}$ in diameter and $2 \mathrm{~mm}$ thick) were polished using sand-paper and polishing cloths to optical transparency. The samples were sputtered with $\sim 50 \mathrm{~nm}$ thick ion-blocking gold electrodes on both sides of the sample. Silver wires were then attached to the gold electrodes with silver conductive ink. Ionic conductivity values were determined with electrochemical impedance spectroscopy measurements using a Gamry Instruments Series G750 potentiostat with four probes in the potentiostatic mode. The applied voltage and ac perturbations were $0 \mathrm{~V}$ and $1 \mathrm{~V}$, respectively, over a frequency range of $10 \mathrm{~Hz}$ to $300 \mathrm{KHz}$ and a temperature range of $300 \mathrm{~K}$ to $673 \mathrm{~K}$.

\section{Results and Discussion}

The vitreous state of the samples was inspected by PXRD and DSC/DTA. The absence of any sharp peak in the diffraction pattern (Fig. 1) and the observation of the glass transition phenomenon in DSC/DTA curve $\mathrm{Na}_{3-\mathrm{x}} \mathrm{Li}_{\mathrm{x}} \mathrm{CaTi}\left(\mathrm{PO}_{4}\right)_{3}(0 \leq \mathrm{x} \leq 3)$ glass compositions (see 3.2 section) confirm their vitreous state 


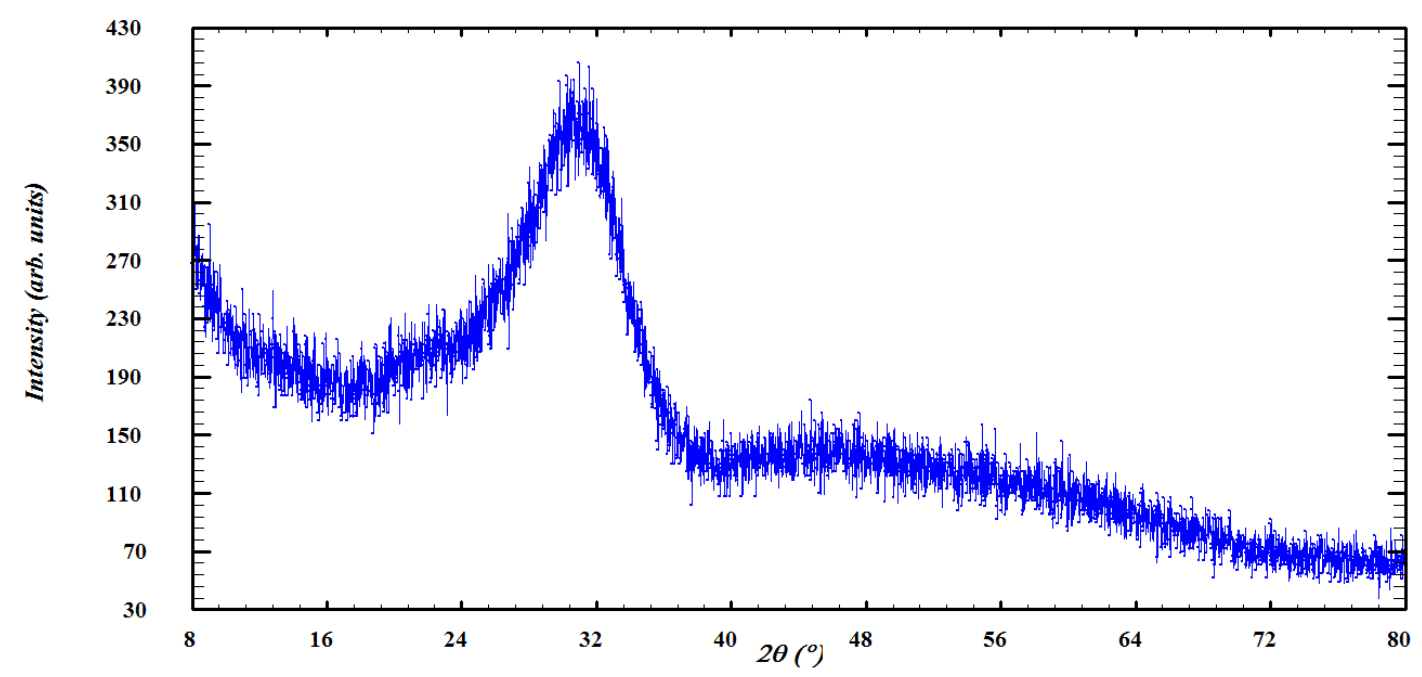

Figure 1. X-ray diffraction pattern of $\mathrm{Na}_{3} \mathrm{CaTi}\left(\mathrm{PO}_{4}\right)_{3}$ glass

\section{Density and molar volume}

Density and molar volume values of $\mathrm{Na}_{3}$ ${ }_{x} \mathrm{Li}_{\mathrm{x}} \mathrm{CaTi}\left(\mathrm{PO}_{4}\right)_{3}(0 \leq \mathrm{x} \leq 3)$ glasses are reported in Table 1 . The density values vary in the range between 2.32 and $2.85 \mathrm{~g} / \mathrm{cm}^{3}$. The substitution of sodium for lithium-ion is accompanied with a non-linearity in density variation. The density passes through a minimum for the composition $\mathrm{x}=1.5$ as well as the molar volume passes through a maximum (Fig. 2). This non-linear behavior has already been observed in other glasses ${ }^{24-27}$.

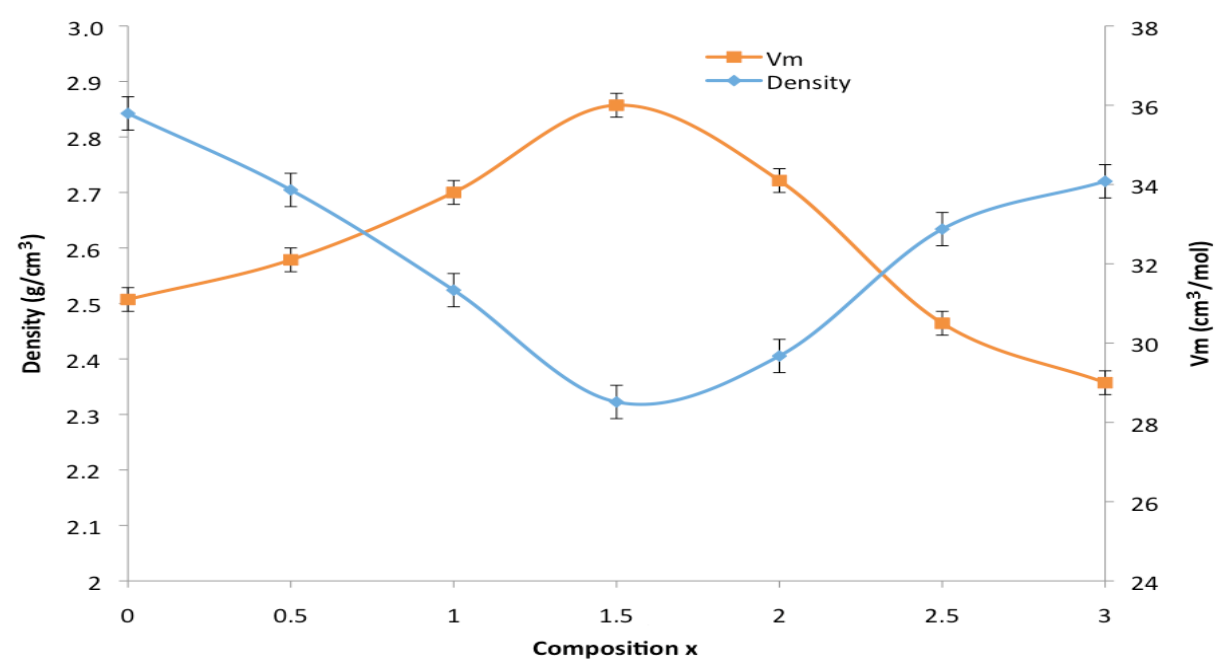

Figure 2. Evolution of density and molar volume of $\mathrm{Na}_{3-\mathrm{x}} \mathrm{Li}_{\mathrm{x}} \mathrm{CaTi}\left(\mathrm{PO}_{4}\right)_{3}(0 \leq \mathrm{x} \leq 3)$ glasses versus lithium content.

\section{DSC/DTA study}

Figure 3 shows DSC/DTA curves of $\mathrm{Na}_{3}$ ${ }_{x} \mathrm{Li}_{\mathrm{x}} \mathrm{CaTi}\left(\mathrm{PO}_{4}\right)_{3}(0 \leq \mathrm{x} \leq 3)$ glasses. All glasses exhibit an endothermic change due to glass transition $\left(\mathrm{T}_{\mathrm{g}}\right)$, followed by an exothermic change due to crystallization $\left(\mathrm{T}_{\mathrm{c}}\right)$, then an endothermic change due to the melting $\left(\mathrm{T}_{\mathrm{m}}\right)$ of the crystalline phases. Table 1 shows the values of the characteristic temperatures $\left(T_{g}, T_{c}, T_{m}\right) . T_{g}$ was determined as the inflexion point of the first endothermic peak, $T_{c}$ as the maximum of the exothermic peak, and $\mathrm{T}_{\mathrm{m}}$ as the minimum of the second endothermic peak.
Some glass compositions show more than one value of $T_{c}$ and $T_{m}$ because their crystallization leads to a mixture of phases, and each phase has its crystallization and melting temperatures. We gave in Table 1 only the values of the first peak. The drift observed, between $T_{g}$ and $T_{c}$, in DTA thermograms of some glass compositions, is probably due to the relaxation phenomenon of glasses ${ }^{28}$. Fig. 4 shows the variation of $T_{g}$ versus lithium content $x(0 \leq x \leq 3)$. As it can be seen in this Figure, $T_{g}$ becomes minimum around the composition $\mathrm{x}=1.5$ then increases. This non-linear behavior was observed in other glasses ${ }^{24-27}$. 


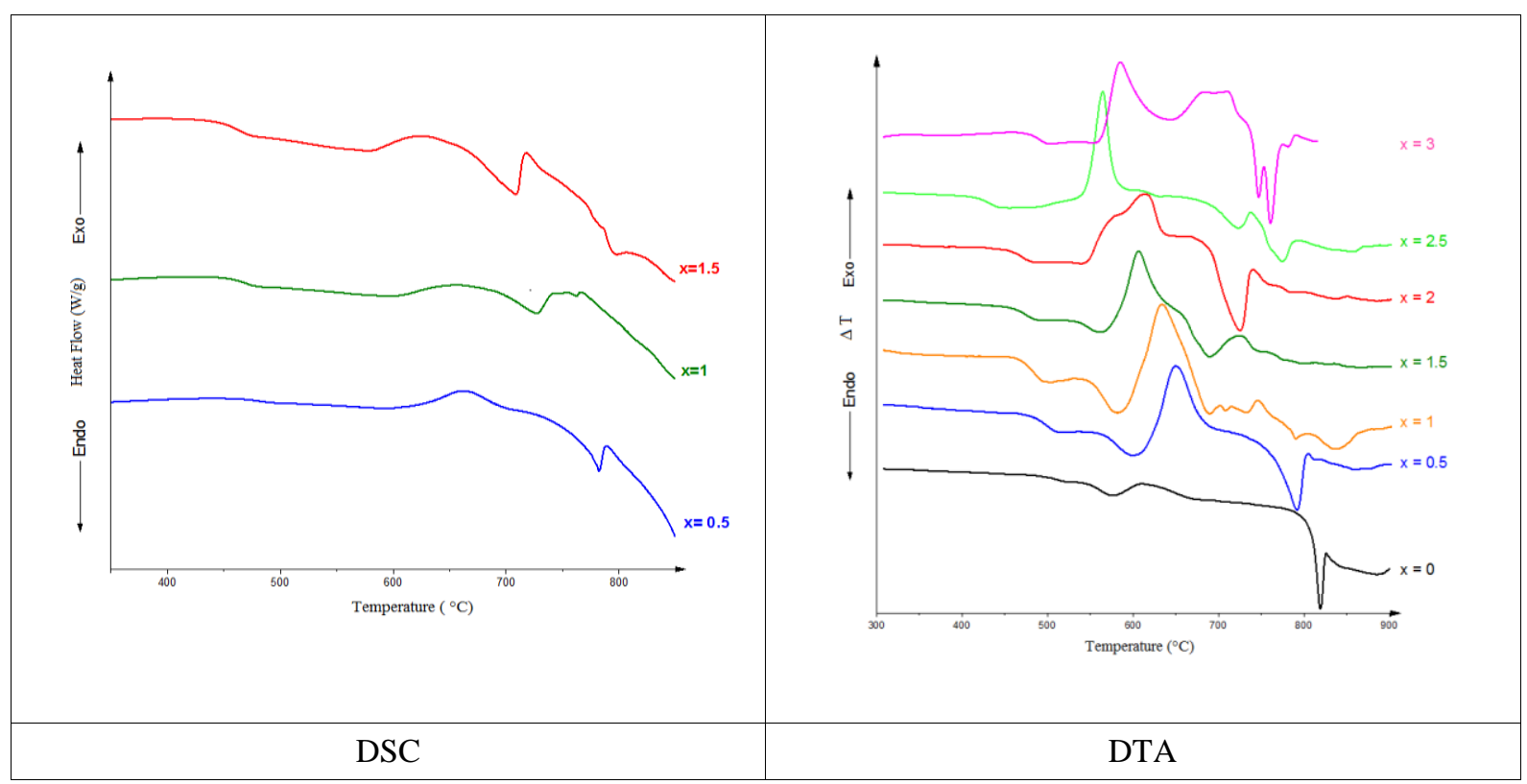

Figure 3. DSC/DTA curves of $\mathrm{Na}_{3-\mathrm{x}} \mathrm{Li}_{\mathrm{x}} \mathrm{CaTi}\left(\mathrm{PO}_{4}\right)_{3}$ glasses $(0 \leq \mathrm{x} \leq 3)$

Table 1. Values of molar mass $(M)$, density $(\rho)$, molar volume $\left(V_{m}\right)$, characteristic temperatures $\left(T_{g}, T_{c}, T_{m}\right)$, and ionic conductivity $\left(\sigma_{300^{\circ} \mathrm{C}}\right)$ for $\mathrm{Na}_{3-\mathrm{x}} \mathrm{Li}_{\mathrm{x}} \mathrm{CaTi}\left(\mathrm{PO}_{4}\right)_{3}(0 \leq \mathrm{x} \leq 3)$ glasses.

\begin{tabular}{|c|c|c|c|c|c|c|c|c|c|c|}
\hline \multirow{2}{*}{$\mathrm{X}$} & \multirow{2}{*}{$\begin{array}{c}\mathrm{M} \\
(\mathrm{g} / \mathrm{mol})\end{array}$} & \multirow{2}{*}{$\begin{array}{c}\rho \\
( \pm 0.03 \\
\left.\mathrm{g} / \mathrm{cm}^{3}\right)\end{array}$} & \multirow{2}{*}{$\begin{array}{c}\mathrm{V}_{\mathrm{m}} \\
( \pm 0.3 \\
\left.\mathrm{cm}^{3} / \mathrm{mol}\right)\end{array}$} & \multicolumn{2}{|c|}{$\begin{array}{c}\mathrm{T}_{\mathrm{g}} \\
\left( \pm 5^{\circ} \mathrm{C}\right)\end{array}$} & \multicolumn{2}{|c|}{$\begin{array}{c}\mathrm{T}_{\mathrm{c}} \\
\left( \pm 5^{\circ} \mathrm{C}\right)\end{array}$} & \multicolumn{2}{|c|}{$\begin{array}{c}\mathrm{T}_{\mathrm{m}} \\
\left( \pm 5^{\circ} \mathrm{C}\right)\end{array}$} & \multirow{2}{*}{$\begin{array}{c}\sigma_{300^{\circ} \mathrm{C}} \\
\left(\mathrm{S} . \mathrm{cm}^{-1}\right) \\
\times 10^{6}\end{array}$} \\
\hline & & & & DTA & DSC & DTA & DSC & DTA & DSC & \\
\hline 0 & 88.37 & 2.85 & 31.1 & 506 & 506 & 610 & - & 820 & - & 13.6 \\
\hline 0.5 & 86.76 & 2.71 & 32.1 & 486 & 482 & 640 & 660 & 789 & 784 & 2.6 \\
\hline 1.0 & 85.16 & 2.52 & 33.8 & 474 & 473 & 625 & 656 & 776 & 773 & 1.4 \\
\hline 1.5 & 83.55 & 2.32 & 36.0 & 467 & 466 & 600 & 623 & 680 & 707 & 2.1 \\
\hline 2.0 & 81.95 & 2.41 & 34.1 & 468 & - & 570 & - & 711 & - & 10.1 \\
\hline 2.5 & 80.34 & 2.63 & 30.5 & 476 & 472 & 558 & - & 711 & - & - \\
\hline 3.0 & 78.74 & 2.72 & 29.0 & 483 & 481 & 577 & - & 733 & - & - \\
\hline
\end{tabular}

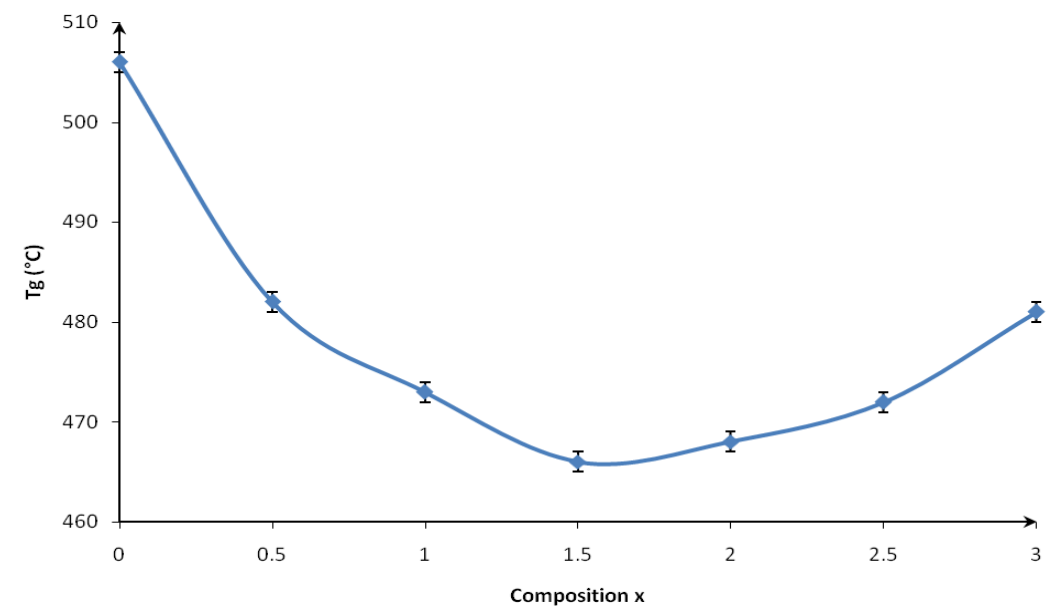

Figure 4. Variation of glass transition temperature $\left(\mathrm{T}_{\mathrm{g}}\right)$ of $\mathrm{Na}_{3-\mathrm{x}} \mathrm{Li}_{\mathrm{x}} \mathrm{CaTi}\left(\mathrm{PO}_{4}\right)_{3}(0 \leq \mathrm{x} \leq 3)$ glasses versus lithium content. 


\section{Crystallization of the glasses}

Crystallization of $\mathrm{Na}_{3-\mathrm{x}} \mathrm{Li}_{\mathrm{x}} \mathrm{CaTi}\left(\mathrm{PO}_{4}\right)_{3}(0 \leq \mathrm{x} \leq 3)$ glasses consists of annealing the samples for 14 hours at $650{ }^{\circ} \mathrm{C}$. The PXRD patterns of the crystalline compounds obtained are shown in Fig. 5. The patterns of the composition $\mathrm{x}=0\left[\mathrm{Na}_{3} \mathrm{CaTi}\left(\mathrm{PO}_{4}\right)_{3}\right]$ and $\mathrm{x}=0.5$ $\left[\mathrm{Na}_{2.5} \mathrm{Li}_{0.5} \mathrm{CaTi}\left(\mathrm{PO}_{4}\right)_{3}\right]$ show the presence of a Nasicon-type phase with very low intensity extra peaks. The other compositions correspond to a mixture of phases (Table 2). $\mathrm{Na}_{3} \mathrm{CaTi}\left(\mathrm{PO}_{4}\right)_{3}{ }^{22}$ and
$\mathrm{Na}_{2.5} \mathrm{Li}_{0.5} \mathrm{CaTi}\left(\mathrm{PO}_{4}\right)_{3} \quad$ crystallize in the trigonal system, space group R32. The equivalent hexagonal cell parameters are: $a_{h}=8.985(4) \AA, c_{h}=21.920(8) \AA$, $\mathrm{V}=1533(2) \AA^{3}$ for $\mathrm{Na}_{3} \mathrm{CaTi}\left(\mathrm{PO}_{4}\right)_{3}$ and $\mathrm{a}_{\mathrm{h}}=8.921(4)$ $\AA, \quad c_{h}=21.908 \quad(8) \AA, \quad V=1510$ (2) $\AA^{3}$ for $\mathrm{Na}_{2.5} \mathrm{Li}_{0.5} \mathrm{CaTi}\left(\mathrm{PO}_{4}\right)_{3}$. The decrease of the cell parameters when lithium replaces sodium can be explained by the size of $\mathrm{Li}^{+}(0.74 \AA)$, which is smaller than that of $\mathrm{Na}^{+}(1.02 \AA)$.

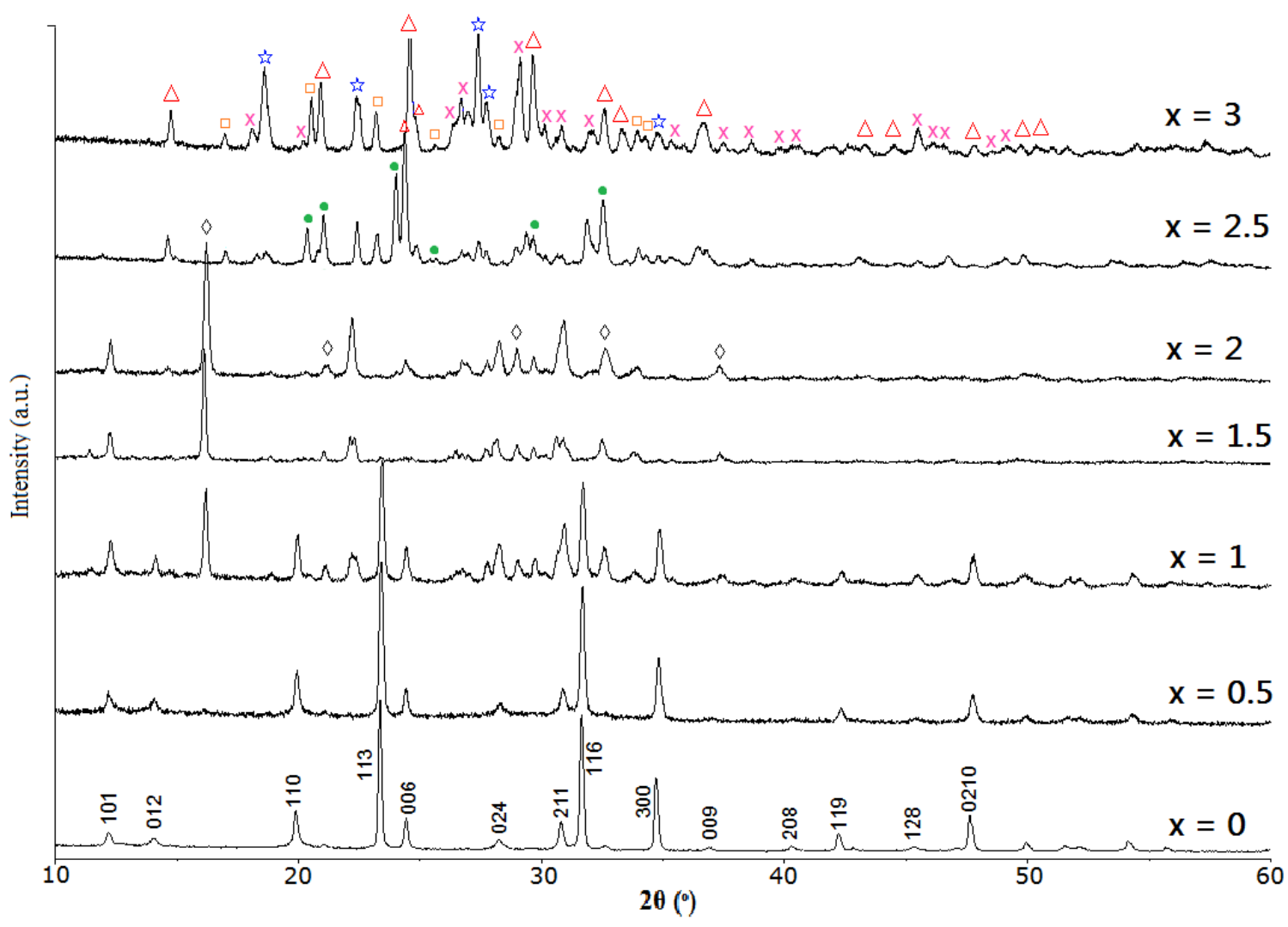

Figure 5. PXRD patterns of samples obtained by crystallization of $\mathrm{Na}_{3-\mathrm{x}} \mathrm{Li}_{\mathrm{x}} \mathrm{CaTi}\left(\mathrm{PO}_{4}\right)_{3}(0 \leq \mathrm{x} \leq 3)$ glasses

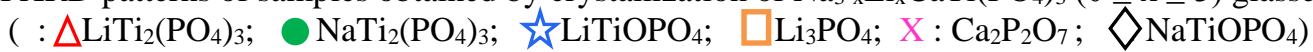

\section{Raman spectroscopy}

Fig. 6 shows Raman spectra of $\mathrm{Na}_{3}$ ${ }_{x} \mathrm{Li}_{\mathrm{x}} \mathrm{CaTi}\left(\mathrm{PO}_{4}\right)_{3}(0 \leq \mathrm{x} \leq 3)$ glasses in the frequency region between 100 and $1500 \mathrm{~cm}^{-1}$. The frequency values and their attributions are given in Table 2 . According to Fig. 6, the Raman spectra are very similar to those reported for $\mathrm{Na}_{3} \mathrm{Ca}_{1-\mathrm{x}} \mathrm{Mn}_{\mathrm{x}} \mathrm{Ti}\left(\mathrm{PO}_{4}\right)_{3}(0$ $\leq \mathrm{x} \leq 1)$ glasses ${ }^{29}$. The peaks observed in the highfrequency region, $850-1250 \mathrm{~cm}^{-1}$, are due to the $\mathrm{P}-\mathrm{O}$ stretching modes of monophosphate $\left(\mathrm{PO}_{4}\right)$ and diphosphate $\left(\mathrm{P}_{2} \mathrm{O}_{7}\right)$ groups ${ }^{30-34}$. The peak at $\sim 1035$ $\mathrm{cm}^{-1}$, relatively sharp, is due to the diphosphate $\mathrm{P}_{2} \mathrm{O}_{7}{ }^{4-}$ ions ${ }^{33,34}$. The presence of a strong peak at $\sim 750 \mathrm{~cm}^{-1}$, observed in titanium oxyphosphates and assigned to Ti-O vibrations in the -Ti-O-Ti-O- chains ${ }^{35,36}$, indicates that the glass structure contains $\mathrm{TiO}_{6}$ octahedra linked by corners to form short -Ti-O-Ti-Ochains. Probably, these chains are linked by distorted $\mathrm{PO}_{4}$ tetrahedra to form -O-P-O-Ti-O- linkage. The peaks observed between 400 and $640 \mathrm{~cm}^{-1}$ are attributed to O-P-O deformations ( $v_{2}$ and $v_{4} \mathrm{PO}_{4}$ modes) and possibly to Ti-O vibrations of $\mathrm{TiO}_{6}$ octahedra. The broad band observed between 200 and $400 \mathrm{~cm}^{-1}$, with a maximum of around $280 \mathrm{~cm}^{-1}$, is attributed to lattice vibrations. As can be observed from Fig. 6, and Table 2 no significant change is observed in the spectra when lithium replaces sodium, indicating that $\mathrm{Li}^{+}$ions do not modify significantly the structure of the glass forming-network, and are located in the interstitial sites. 


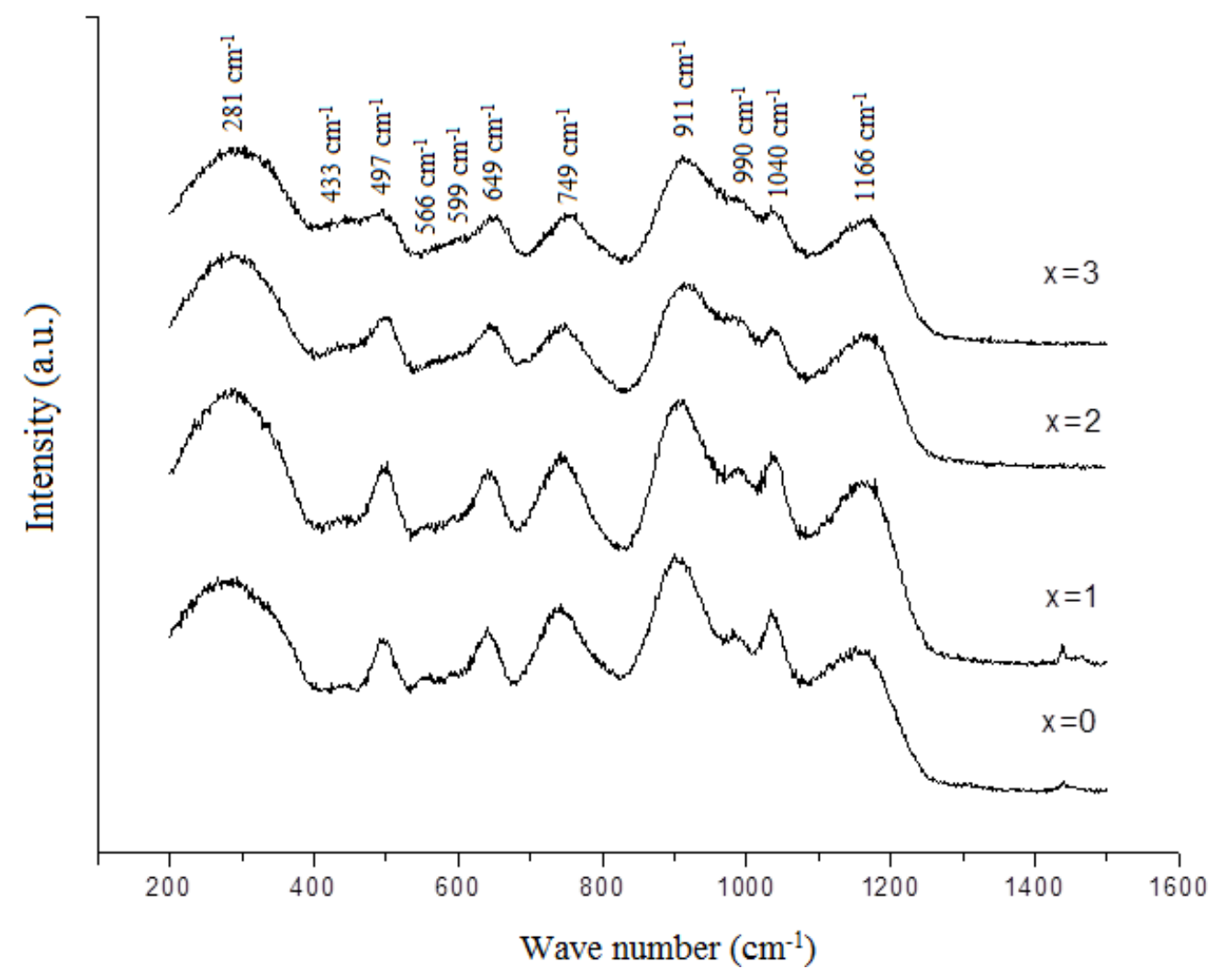

Figure 6. Raman spectra of $\mathrm{Na}_{3-\mathrm{x}} \mathrm{Li}_{\mathrm{x}} \mathrm{CaTi}\left(\mathrm{PO}_{4}\right)_{3}(0 \leq \mathrm{x} \leq 3)$ glasses.

Table 2. Raman band assignments of $\mathrm{Na}_{3-\mathrm{x}} \mathrm{Li}_{\mathrm{x}} \mathrm{CaTi}\left(\mathrm{PO}_{4}\right)_{3}(0 \leq \mathrm{x} \leq 3)$ glasses (w: weak, vw: very weak, m: medium, s: strong, vs: very strong).

\begin{tabular}{|c|c|c|c|c|}
\hline \multicolumn{4}{|c|}{ Wave number $\left(\mathrm{cm}^{-1}\right)$} & \multirow{2}{*}{ Band assignment } \\
\hline $\mathrm{x}=0$ & $\mathrm{x}=1$ & $x=2$ & $x=3$ & \\
\hline $\begin{array}{l}1160 \mathrm{~m} \\
1032 \mathrm{~s} \\
990 \mathrm{w} \\
909 \mathrm{vs}\end{array}$ & $\begin{array}{l}1164 \mathrm{~m} \\
1041 \mathrm{~s} \\
995 \mathrm{w} \\
911 \mathrm{vs}\end{array}$ & $\begin{array}{l}1167 \mathrm{~m} \\
1041 \mathrm{~s} \\
991 \mathrm{w} \\
915 \mathrm{vs}\end{array}$ & $\begin{array}{l}1166 \mathrm{~m} \\
1040 \mathrm{~s} \\
990 \mathrm{w} \\
911 \mathrm{vs}\end{array}$ & $\begin{array}{c}\text { P-O stretching modes } \\
v_{3}\left(\mathrm{PO}_{4}^{3-}\right), v_{1}\left(\mathrm{PO}_{4}^{3-}\right) \\
+ \\
\text { P-O-P deformations }\end{array}$ \\
\hline $744 \mathrm{~s}$ & $744 \mathrm{~s}$ & $745 \mathrm{~s}$ & $749 \mathrm{~s}$ & $\begin{array}{l}\text { P-O-P symmetric stretching }+ \\
\text { Ti-O vibrations in }(-\mathrm{Ti}-\mathrm{O}-\mathrm{Ti}-) \text { chain }\end{array}$ \\
\hline $\begin{array}{l}644 \mathrm{~m} / \mathrm{s} \\
593 \mathrm{vw} \\
557 \mathrm{vw} \\
494 \mathrm{~m} / \mathrm{s} \\
438 \mathrm{vw} \\
\end{array}$ & $\begin{array}{l}648 \mathrm{~m} / \mathrm{s} \\
596 \mathrm{vw} \\
557 \mathrm{vw} \\
498 \mathrm{~m} / \mathrm{s} \\
438 \mathrm{vw} \\
\end{array}$ & $\begin{array}{l}649 \mathrm{~m} / \mathrm{s} \\
600 \mathrm{vw} \\
563 \mathrm{vw} \\
503 \mathrm{~m} / \mathrm{s} \\
438 \mathrm{vw}\end{array}$ & $\begin{array}{l}649 \mathrm{~m} / \mathrm{s} \\
599 \mathrm{vw} \\
566 \mathrm{vw} \\
497 \mathrm{~m} / \mathrm{s} \\
433 \mathrm{vw} \\
\end{array}$ & $\begin{array}{c}\text { O-P-O deformations } \\
v_{2}\left(\mathrm{PO}_{4}^{3-}\right), v_{4}\left(\mathrm{PO}_{4}{ }^{3-}\right) \\
+ \\
\text { Ti-O vibrations of } \mathrm{TiO}_{6} \text { octahedra }\end{array}$ \\
\hline $280 \mathrm{vs}$ & $283 \mathrm{vs}$ & $288 \mathrm{vs}$ & $281 \mathrm{vs}$ & Lattice vibrations (external modes) \\
\hline
\end{tabular}

\section{Ionic conductivity}

Ionic conductivity measurements were completed for all $\mathrm{Na}_{3-\mathrm{x}} \mathrm{Li}_{\mathrm{x}} \mathrm{CaTi}\left(\mathrm{PO}_{4}\right)_{3}(0 \leq \mathrm{x} \leq 3)$ glass compositions, however, for $\mathrm{x}=2.5$ and $\mathrm{x}=3$, the resistance at room temperature was so high that it was impossible to measure it. The Nyquist plots, at different temperatures, are shown in Fig. 7, for two glass compositions $(\mathrm{x}=0 ; 2)$. They exhibit complete semicircles at a higher frequency, a clear local minimum, and then the impedance increases at low frequency. At $300^{\circ} \mathrm{C}$ it is clear that the low frequency impedance continuously increases, indicating the samples are pure ion conductors. Similar impedance behavior was observed for $\mathrm{x}=0.5 ; 1$ and 1.5. The local minimum of the semicircle corresponds to the bulk resistance (R) and shifts to lower Z' values with increasing temperature, indicating that the $\mathrm{dc}$ conductivity is a thermally activated process. Ionic conductivity was calculated using the formula $\sigma=$ $\mathrm{e} /(\mathrm{R} . \mathrm{S})$, where e and $\mathrm{S}$ are respectively the thickness and the surface area of the glass disc, and $\mathrm{R}$ its resistance. Ionic conductivity variation follows the Arrhenius law: $\sigma=(\mathrm{A} / \mathrm{T}) \quad \exp (-\mathrm{Ea} / \mathrm{kT})$ $(\sigma:$ conductivity, A: pre-exponential factor, $\mathrm{k}$ : Boltzmann constant, $\mathrm{T}$ : temperature, $\mathrm{E}_{\mathrm{a}}$ : activation energy). Values of the ionic conductivity at $300^{\circ} \mathrm{C}$ are given in Table 1 . The $\log (\sigma \mathrm{T})$ vs $1 / \mathrm{T}$ plots are displayed in Fig. 8. 
Ionic conductivity variation of these glasses, versus alkali ion content, shows a non-linear evolution (Fig. 9), as observed above for density, molar volume and glass transition temperature. The same behavior of conductivity was observed in other vitreous systems and was attributed to the mixed alkali ions effect (MAE) ${ }^{26,27,37-39}$. The effect of $\mathrm{Li}^{+}$ions in $\mathrm{Na}_{3-\mathrm{x}} \mathrm{Li}_{\mathrm{x}} \mathrm{CaTi}\left(\mathrm{PO}_{4}\right)_{3}(0 \leq \mathrm{x} \leq 3)$ glasses can be observed as a decrease in the conductivity giving rise to a minimum at the composition $\mathrm{x}=1$. For low lithium content $\left(\mathrm{Li}_{2} \mathrm{O} / \mathrm{Na}_{2} \mathrm{O} \leq 1 ; \mathrm{x} \leq 1.5\right)$, the conductivity is governed by $\mathrm{Na}^{+}$ions, but their mobility is hampered by $\mathrm{Li}^{+}$ions. In contrary, for low sodium content, the conductivity is governed by $\mathrm{Li}^{+}$ ions, but their mobility is hampered by $\mathrm{Na}^{+}$ions. This means that the two types of alkali ions $\left(\mathrm{Na}^{+}\right.$and $\left.\mathrm{Li}^{+}\right)$ have distinctly different conduction pathways, and implies that $\mathrm{Li}^{+}$ions tend to block the pathways for the $\mathrm{Na}^{+}$ions and vice versa. We suppose that this is the main reason for the MAE. Our hypothesis was based on the dynamic structure model (DSM) ${ }^{40,41}$, which gives a theoretical explanation of this effect. By definition, the MAE occurs when two types of alkali ions are introduced into a glassy network. The progressive substitution of an alkali ion for another, while total alkali content in the glass being constant, is often accompanied by non-linear variations in physical properties related to the alkali ion movement and structure properties ${ }^{42,43}$. The DSM suggests that the two alkali ions can create their proper distinct local environments in the glass. Consequently, two preferred diffusion paths for each type of ion are formed which are dependent on the ionic composition and provide a possible explanation for the MAE.

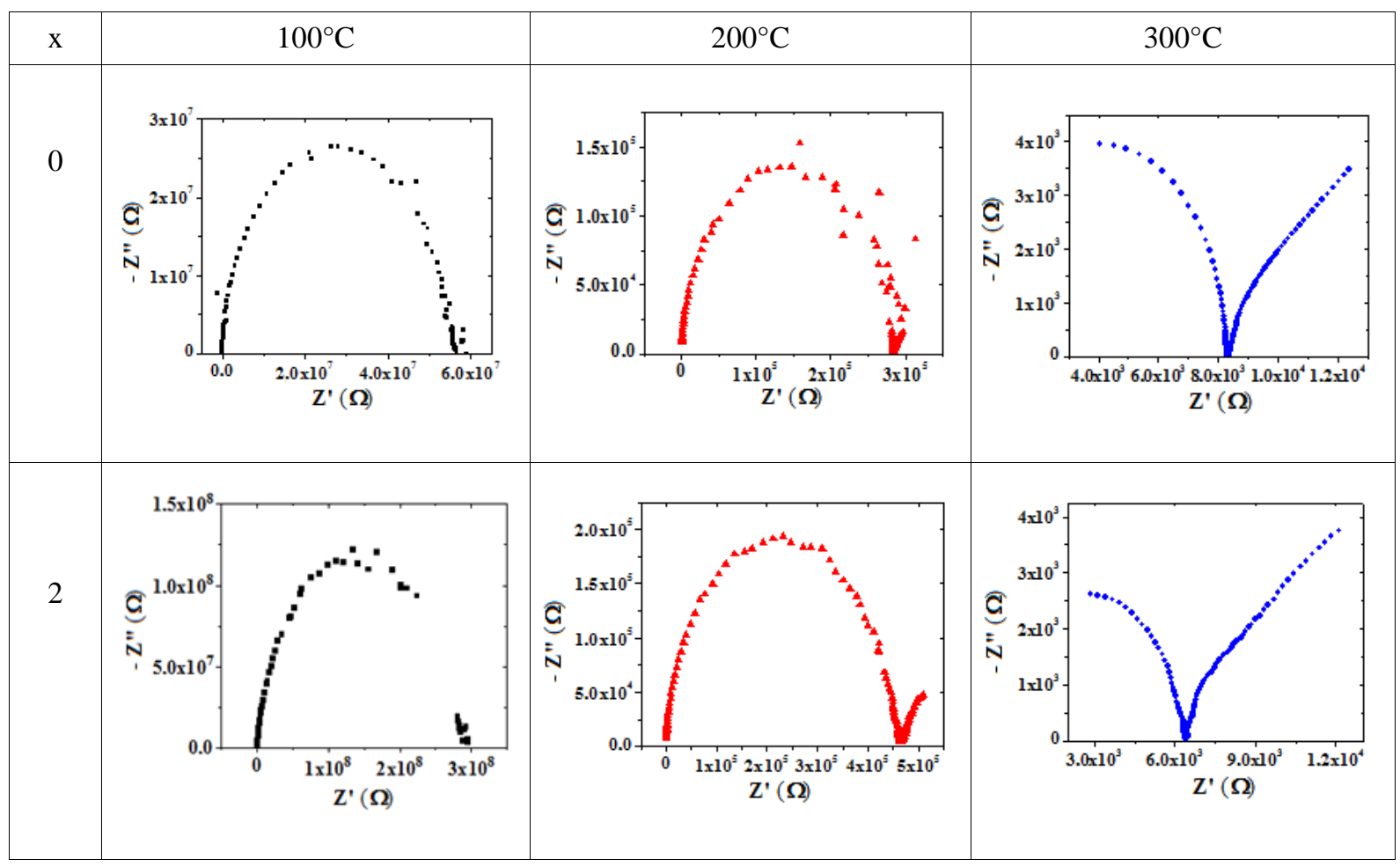

Figure 7. Nyquist plots of $\mathrm{Na}_{3-\mathrm{x}} \mathrm{Li}_{\mathrm{x}} \mathrm{CaTi}\left(\mathrm{PO}_{4}\right)_{3}(\mathrm{x}=0 ; 2)$ glasses at different temperatures.

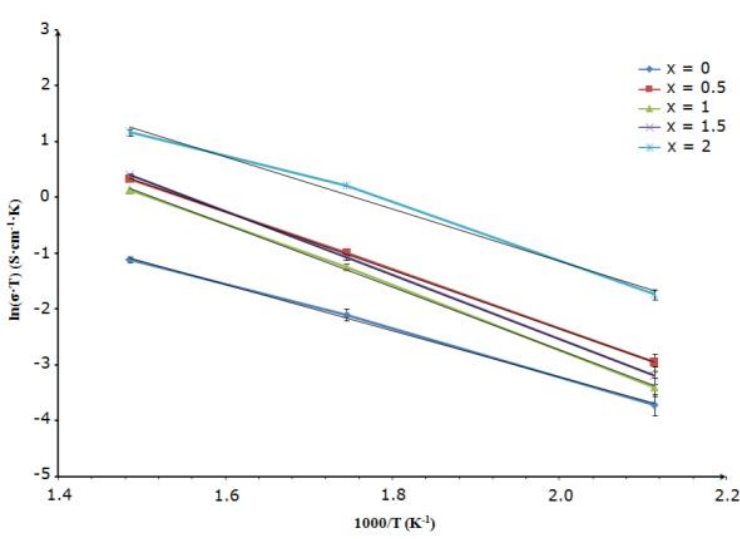

Figure 8. Arrhenius plots of conductivity of $\mathrm{Na}_{3}$ ${ }_{x} \operatorname{Li}_{x} \mathrm{CaTi}\left(\mathrm{PO}_{4}\right)_{3}(0 \leq \mathrm{x} \leq 2)$ glasses

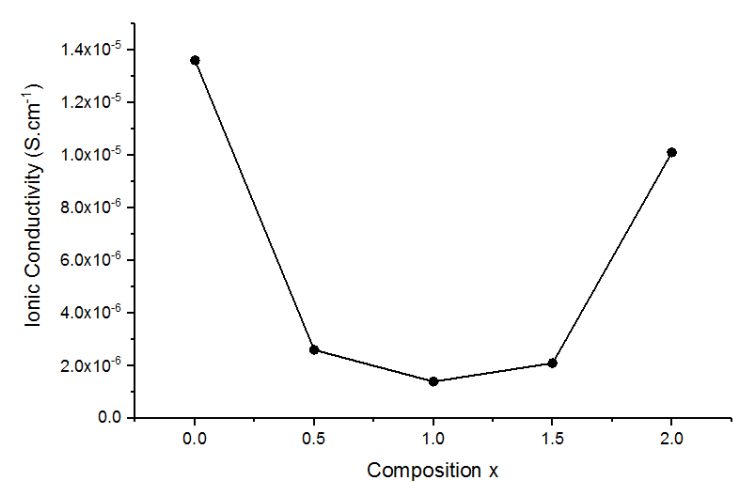

Figure 9. Variation of conductivity at $300{ }^{\circ} \mathrm{C}$ versus composition $\mathrm{x}$ of $\mathrm{Na}_{3-\mathrm{x}} \mathrm{Li}_{\mathrm{x}} \mathrm{CaTi}\left(\mathrm{PO}_{4}\right)_{3}(0 \leq \mathrm{x} \leq 2)$ glasses 


\section{Conclusion}

Structural and physical properties of $\mathrm{Na}_{3}$ ${ }_{x} \operatorname{Li}_{\mathrm{x}} \mathrm{CaTi}\left(\mathrm{PO}_{4}\right)_{3}(0 \leq \mathrm{x} \leq 3)$ glasses have been studied. When $\mathrm{Na}^{+}$is gradually replaced by $\mathrm{Li}^{+}$, density, molar volume, glass transition temperature and ionic conductivity vary in a non-linear manner, as a result of the mixed alkali ions effect. Crystallization of the glasses leads to the formation of a Nasicon phase for the compositions $\mathrm{x}=0$ and $\mathrm{x}=0.5$, and to a mixture of phases for the other compositions. Raman spectroscopy study shows that the glasses contain $\mathrm{P}_{2} \mathrm{O}_{7}, \mathrm{PO}_{4}$ groups and short -Ti-O-Ti-O-Ti- chains, probably linked by distorted $\mathrm{PO}_{4}$ tetrahedra. One can conclude that the glass structure is based on -Ti-O-Pand -Ti-O-Ti-O- linkages.

\section{Acknowledgements}

Financial support from the "Agence Universitaire de la Francophonie - AUF” (Grant $N^{\circ}$ PSCI59113PSO24) is gratefully acknowledged. F.E.D. and A.E.J. thank the Moroccan American Commission for Educational and Cultural Exchanges - Fulbright's Program (www.macece.org) for its financial support. They also acknowledge the support of the Department of Chemistry and the Center for Energy, Environment, and Sustainability at Wake Forest University, during their stay at WFU.

\section{References}

1- M. Minakshi, D. Mitchell, R. Jones,

F. Alenazey, T. Watcharatharapong,

S. Chakraborty, R. Ahuja, Synthesis, structural and electrochemical properties of sodium nickel phosphate for energy storage devices, Nanoscale, 2016, 8, 11291-11305.

2- V. Rajendran, A. V. Gayathri Devi, M. Azooz, F. H. El-Batal, Physicochemical studies of phosphate based $\mathrm{P}_{2} \mathrm{O}_{5}-\mathrm{Na}_{2} \mathrm{O}-\mathrm{CaO}-\mathrm{TiO}_{2}$ glasses for biomedical applications, J. NonCryst. Solids, 2007, 353, 77-84.

3- N. Lyczko, A. Nzihou, P. Sharrock, Calcium phosphate sorbent for environmental application, Procedia Engineer., 2014, 83, 423-431.

4- A. Serghini, R. Brochu, M. Ziyad, J. C. Vedrine, Synthesis, characterization and catalytic behavior of $\mathrm{Cu}_{0.5} \mathrm{M}_{2}\left(\mathrm{PO}_{4}\right)_{3}(\mathrm{M}=\mathrm{Zr}$, Sn, Ti), J. Alloy. Compd., 1992, 188, 60-64.

5- A. El Jazouli, A. El Bouari, H. Fakrane, A. Housni, I. Mansouri, R. Olazcuaga, G. Le Flem, Crystallochemistry and structural study of some Nasicon-like phosphates, J. Alloy. Compd., 1997, 262-263, 49-53.

6- N. Anantharamulu, K. K. Rao, G. Rambabu, B. V. Kumar, V. Radha, M. Vithal, A wideranging review on Nasicon type materials, J. Mater. Sci., 2011, 46, 2821-2837.

7- A. Aatiq, C. Delmas, A. El Jazouli, Structural and electrochemical study of
$\mathrm{Li}_{0.5} \mathrm{Mn}_{0.5} \mathrm{Ti}_{1.5} \mathrm{Cr}_{0.5}\left(\mathrm{PO}_{4}\right)_{3}$, J. Solid. State. Chem., 2001, 1006, 169-174.

8- A. Aatiq, M. Ménétrier, A. El Jazouli, C. Delmas, Structural and lithium intercalation of $\mathrm{Mn}_{(0.5-\mathrm{x})} \mathrm{Ca}_{\mathrm{x}} \mathrm{Ti}_{2}\left(\mathrm{PO}_{4}\right)_{3}$ phases $(0 \leq \mathrm{x} \leq 0.5)$, Solid State Ionics, 2002, 150, 391-405.

9- J. B. Goodenough, H. -P. Hong, J. A. Kafalas, Fast $\mathrm{Na}^{+}$-ion transport in skeleton structures, Mater. Res. Bull., 1976, 11, 203-220.

10- C. Delmas, J. -C. Viala, R. Olazcuaga, G. Le Flem, P. Hagenmuller, F. Cherkaoui, R. Brochu, Ionic conductivity in Nasicon-type phases $\mathrm{Na}_{1+\mathrm{x}} \mathrm{Zr}_{2-\mathrm{x}} \mathrm{L}_{\mathrm{x}}\left(\mathrm{PO}_{4}\right)_{3}(\mathrm{~L}=\mathrm{Cr}, \mathrm{In}, \mathrm{Yb})$, Solid State Ionics, 1981, 3-4, 209-214.

11- R. Roy, D. K. Agrawal, J. Alamo, R. A. Roy, CTP-: A new structural family of near-zero expansion ceramics, Mater. Res. Bull., 1984, 19, 471-477.

12- V. I. Pet'kov, E. A. Asabina, I. A. Shchelokov, Thermal expansion of Nasicon materials, Inorg. Mater, 2013, 49, 502-506.

13- A. El Jazouli, A. Nadiri, J. M. Dance, C. Delmas, G. Le Flem, Relationships between structure and magnetic properties of titanium (III) Nasicon type phosphates, J. Phys. Chem. Solids, 1988, 49, 779-783.

14- J. Derouet, L. Beaury, P. Porcher, R. Olazcuaga, J. M. Dance, G. Le Flem, A. El Bouari, A. El Jazouli, A new Nasicon-type phosphate: $\mathrm{Co}_{0.5} \mathrm{Ti}_{2}\left(\mathrm{PO}_{4}\right)_{3}$ II. Simulation of optical and magnetic properties, J. Solid State Chem., 1999, 143, 230-238.

15- A. Mouline, M. Alami, R. Brochu, R. Olazcuaga, C. Parent, G. Le Flem, Structural and luminescent properties of a Nasicon-type phosphate $\mathrm{Cu}_{0.5}^{\mathrm{I}} \mathrm{Mn}^{\mathrm{II}}{ }_{0.25} \mathrm{Zr}_{2}\left(\mathrm{PO}_{4}\right)_{3}$, J. Solid State Chem., 2000, 152, 453-459.

16- Z. Jian, Y. S. Hu, X. Ji, W. Chen, Nasiconstructured materials for energy storage, Adv. Mater., 2017, 29, 1-16.

17- S. Susman, C. J. Delbecq, J. A. McMillan, M. F. Roche, Nasiglass: a new vitreous electrolyte, Solid State Ionics, 1983, 9-10, 667-673.

18- A. El Jazouli, Vitrification of phosphates of Nasicon-type structure, Adv. Mat. Res., 1994, 1-2, 105-114.

19- C. R. Mariappan, G. Govindaraj, B. Roling, Lithium and potassium ion conduction in $\mathrm{A}_{3} \mathrm{TiBP}_{3} \mathrm{O}_{12}(\mathrm{~A}=\mathrm{Li}, \mathrm{K} ; \mathrm{B}=\mathrm{Zn}, \mathrm{Cd})$ Nasicontype glasses, Solid State Ionics, 2005, 176, 723-729.

20- S. Krimi, A. El Jazouli, A. Lachgar, L. Rabardel, D. de Waal, J. R. Ramos-Barrado, Glass-crystal transformation of $\mathrm{Na}_{5-2 \mathrm{x}} \mathrm{Ca} \mathrm{Ti}\left(\mathrm{PO}_{4}\right)_{3}$ phosphates, Ann. Chim.-Sci. Mat., 2000, 25, 75-78.

21- S. Krimi, A. El Jazouli, A. Lachgar and J. R. Ramos-Barrado, Glass-crystal transformation of $\mathrm{Na}_{3} \mathrm{MgTi}\left(\mathrm{PO}_{4}\right)_{3}$, Phosphorus Research Bulletin, 2003, 15, 142-145.

22- S. Krimi, A. El Jazouli, A. Lachgar, Crystal 
structure of the new titanium phosphate $\mathrm{Na}_{3} \mathrm{CaTi}\left(\mathrm{PO}_{4}\right)_{3}$, Acta Cryst., 2007, 63, 291-292.

23- F. E. Dardar, A. El Jazouli, A. Lachgar, M. Gross, C. Day, Vitreous and crystalline phosphates: elaboration and electrical properties, Acta Cryst., 2014, A 70, C1766.

24- J. O. Isard, The mixed alkali effect in glass, J. Non-Cryst. Solids, 1969, 1, 235-261.

25- D. E. Day, Mixed alkali glasses - Their properties and uses, J. Non-Cryst. Solids, 1976, 21, 343-372.

26- H. Jain, H. L. Downing, N. L. Peterson, The mixed alkali effect in lithium - sodium borate glasses, J. Non-Cryst. Solids, 1984, 64, 335-349.

27- J. Swenson, S. Adams, Mixed Alkali Effect in Glasses, Phys. Rev. Lett., 2003, 90, 155507-155510.

28- W. R. Heffner, A Differential Thermal Analysis Apparatus for Exploring the Glass Transition, BFY Proceedings; edited by Eblen-Zayas, Behringer, and Kozminski; the American Association of Physics Teachers, 2015, pp. 36-39.

29- S. Lamrhari, Z. El Khalidi, S. Krimi, M. Haddad, M. Couzi, A. Lachgar, A. El Jazouli, Synthesis and structural characterization of phosphate-based Nasiglasses $\mathrm{Na}_{3} \mathrm{Ca}_{1-\mathrm{x}} \mathrm{Mn}_{\mathrm{x}} \mathrm{Ti}\left(\mathrm{PO}_{4}\right)_{3}(0 \leq \mathrm{x} \leq 1)$, J. Mater. Environ. Sci., 2018, (Accepted).

30- P. Tarte, A. Rulmont, C. Merckaert-Ansay, Vibrational spectrum of nasicon-like, rhombohedral orthophosphates $\mathrm{M}^{\mathrm{I}} \mathrm{M}_{2}{ }^{\mathrm{IV}}\left(\mathrm{PO}_{4}\right)_{3}$, Spectrochim. Acta, 1986, 42A, 1009-1016.

31- R. Pikl, D. De Waal, A. Aatiq, A. El Jazouli, Vibrational spectra and factor group analysis of $\mathrm{Mn}_{(0.5+\mathrm{x})} \mathrm{Ti}_{(2-2 \mathrm{x})} \mathrm{Cr}_{2 \mathrm{x}}\left(\mathrm{PO}_{4}\right)_{3}\{0 \leq \mathrm{x} \leq 0.50\}$, Vib. Spectrosc., 1998, 16, 137-143.

32- R. Pikl, D. De Waal, A. Aatiq, A. El Jazouli, Vibrational Spectra and Factor Group Analysis of $\mathrm{Li}_{2 \mathrm{x}} \mathrm{Mn}_{0.5-\mathrm{x}} \mathrm{Ti}_{2}\left(\mathrm{PO}_{4}\right)_{3}\{\mathrm{x}=0,0.25,0.50\}$, Mater. Res. Bull., 1998, 33, 955-961.

33- D. F. Mullica, H. O. Perkins, D. A. Grossie, Structure of Dichromate-Type Lead
Pyrophosphate, $\mathrm{Pb}_{2} \mathrm{P}_{2} \mathrm{O}_{7}$, J. Solid State Chem., 1986, 62, 371-376.

34- S. Kaoua, S. Krimi, S. Pechev, P. Gravereau, J.P. Chaminade, M. Couzi, A. El Jazouli, Synthesis, crystal structure, and vibrational spectroscopic and UV-visible studies of $\mathrm{Cs}_{2} \mathrm{MnP}_{2} \mathrm{O}_{7}$, J. Solid State Chem., 2013, 198, 379-385.

35- C. E. Bamberger, G. M. Begun, O. B. Cavin, Synthesis and characterization of sodiumtitanium phosphates, $\mathrm{Na}_{4}(\mathrm{TiO})\left(\mathrm{PO}_{4}\right)_{2}$, $\mathrm{Na}(\mathrm{TiO}) \mathrm{PO}_{4}$, and $\mathrm{NaTi}_{2}\left(\mathrm{PO}_{4}\right)_{3}$, J. Solid State Chem., 1988, 73, 317-324.

36- M. Chakir, A. El Jazouli, J. -P. Chaminade, F. Bourée, D. De Waal, New process of preparation, X-ray characterisation, structure and vibrational studies of a solid solution LiTiOAs $_{1-\mathrm{x}} \mathrm{P}_{\mathrm{x}} \mathrm{O}_{4}(0 \leq \mathrm{x} \leq 1)$, J. Solid State Chem., 2006, 179, 18-28.

37- R. Chen, R. Yang, B. Durand, A. Pradel, M. Ribes, A study of the mixed alkali effect by frequency-dependent conductivity in $\mathrm{Li}_{2} \mathrm{O}$ $\mathrm{Na}_{2} \mathrm{O}-\mathrm{P}_{2} \mathrm{O}_{5}$ glasses, Solid State Ionics, 1992, 53-56, 1194-1199.

38- A. Faivre, D. Viviani, J. Phalippou, Mixed alkali effect in $\mathrm{Li}$ and $\mathrm{Na}$ aluminophosphate glasses: influence of the cation environment, Solid State Ionics, 2005, 176, 325-332.

39- Y. Gao, C. Cramer, Mixed cation effects in glasses with three types of alkali ions, Solid State Ionics, 2005, 176, 2279-2284.

40- A. Bunde, M. D. Ingram, P. Maass, The dynamic structure model for ion transport in glasses, J. Non-Cryst. Solids, 1994, 172, 1222-1236.

41- P. Maass, Towards a theory for the mixed alkali effect in glasses, J. Non-Cryst. Solids, 1999, 255, 35-46.

42- D. E. Day, Mixed alkali glasses - Their properties and uses, J. Non-Cryst. Solids, 1976, 21, 343-372.

43- J. O. Isard, The mixed alkali effect in glass, J. Non-Cryst. Solids, 1969, 1, 235-261. 